\title{
DOES THE HEALTH AND SAFETY AT WORK ACT 2015 APPLY TO ROADS?
}

\author{
Murray King*
}

This article examines how far the Health and Safety at Work Act 2015 applies to roads. Road authorities have substantial control over the safe use of their roads and, as roads are a product of work, it might be expected that the Act applies to any deficiencies in that work that create harm, as it does to most areas of the economy. But the Act can be read in a way that limits its applicability to actions that cause harm much later and indeed to public safety in general. The article analyses some key sections of the Act to see how far their duties might extend to road authorities. It concludes that while there is some room for doubt, the Act is capable of supporting a prosecution of a road authority, especially in relation to a work-use vehicle. In addition, the so-called "upstream duties" on designers and others could well create a liability for the authorities. The article nevertheless proposes reforms to clarify the liability.

\section{INTRODUCTION}

In New Zealand and other jurisdictions, rail safety is closely controlled, including the safety of the infrastructure - the track, formation, signalling and structures. For roads, on the other hand, there is much less supervision of the actual road, its construction and condition. Safety is the responsibility of the user, not the provider, except in general terms. For example, if a rock falls on a car and kills someone, then the road owner is unlikely to face civil or regulatory action. ${ }^{1}$ If the same event happened on rail, then at least regulatory action, involving penalties, is likely. The safety burdens thus fall unevenly; nearly all activities in the economy other than roads are subject to at least health and safety legislation, including road's main competitor, rail, which is also subject to

* Transport consultant, Wellington. He recently wrote an LLM dissertation on the differential safety liability of road and rail.

1 A real case where the coroner could only exhort the New Zealand Transport Agency to pay more attention to such risks: Re Heather Joy Thompson Coroners Court Hamilton CSU-2014-HAM-000130 25 September 2014 at [24]. Contrast Lewis (Guardian ad litem of) v British Columbia [1997] 3 SCR 1145; and Just v British Columbia [1989] 2 SCR 1228 where the highway authority was found to be negligent on similar facts. But see Gobin v British Columbia 2002 CarswellBC 1406 (BCCA) where there was no liability because the rock inspection system was held to be a policy decision. 
further regulation. This article examines the extent to which the Health and Safety at Work Act 2015 (HSWA) applies to roads, and whether the Act reduces unevenness of the burden.

\section{CONTEXT}

Road accidents are a serious safety problem in New Zealand. In 2015, there were 9737 road accidents, killing 319 people and injuring 12,270. ${ }^{2}$ The number killed is much greater than those killed in rail-related incidents $(16),{ }^{3}$ or in all work-related accidents outside most transport (43). ${ }^{4}$ Across all employers, there are also more than 226,000 work-related injury claims a year, ${ }^{5}$ including 99 rail injuries. ${ }^{6}$

New Zealand has stringent laws covering employment health and safety, the HSWA; and railway safety, the Railways Act 2005 (RA). The HSWA modernised and extended the coverage of the former Health and Safety in Employment Act 1992 (HSEA), following a major mining accident and subsequent inquiries. The new law is intended to "provide for a balanced framework to ensure the health and safety of workers and workplaces", based on "participation, leadership, and accountability by government, business, and workers". ${ }^{7}$ In theory, it places obligations on those who create risks and can best manage them. ${ }^{8}$

There are also substantial laws covering road user behaviour and vehicle condition, in the Land Transport Act 1998, regulations and rules. The HSWA and the RA cover rail accidents where the infrastructure was at fault through, for example, poor design or maintenance, as well as where individuals were in the wrong. Road user laws cover accidents caused by drivers and vehicles, but there appears to be a dearth of laws covering the responsibilities of the road owner itself, for example for the condition of the road. In exploring whether the HSWA does cover roads and roading authorities, this article is concerned with the interaction of the infrastructure with users, and the safety issues arising from that interaction, not with the authorities' direct or contracted employees, such as at road works, nor with vehicle operation.

2 "Motor Vehicle Crashes in New Zealand 2015" (9 September 2016) Ministry of Transport <www.transport.govt.nz>.

3 Ministry of Transport Rail Safety Statistics: Six monthly statistics for the period ended 31 December 2015 (February 2016) at 14. There were no rail employee deaths.

4 "Workplace fatalities by industry" (28 November 2016) WorkSafe New Zealand <www.worksafe.govt.nz>. The WorkSafe data does not include road, aviation or maritime fatalities, and appears not to include rail.

5 "Injury Statistics - Work-related Claims: 2014" (15 October 2015) Statistics New Zealand <www.statistics.govt.nz>.

6 Ministry of Transport, above n 3, at 14. Half of the injuries were to employees (49).

$7 \quad$ Health and Safety Reform Bill 2014 (192-1) (explanatory note - general policy statement), at 1.

8 At 2 . 


\section{HIGHWAY AUTHORITIES' CONTROL OVER THEIR ROADS}

The extent to which road owners have control of the use of their roads, and road users, is an important point in considering the liability issues. Road owners are typically seen as not having control over the users of roads, whereas a railway company has control over all its activities. Our road safety laws assume driver responsibility. ${ }^{9}$ Under this assumption, drivers need to be ready to deal with all issues on the road, not just their own behaviour or that of other drivers, but also deficiencies in the road. ${ }^{10}$ Road owners have limited, if any, liability. It is a standard international assumption. ${ }^{11}$

This view overlooks the areas where road authorities do have substantial control, such as the physical condition of roads, and also substantial influence, such as in the setting of road use rules and parameters. Roading authorities have physical control over the sources of harm, and control gives them opportunities to create or mitigate dangers that others do not have. ${ }^{12}$ As was observed in a Canadian case, "[t]he [roading authority] is in complete control of repair and maintenance and travellers are dependent upon [the authority] for the reasonable performance of the work". ${ }^{13}$ Users are in "no position to assess the ... construction and maintenance work". ${ }^{14}$

Official road accident statistics indicate that roads do at least contribute to accidents. Police Traffic Crash Reports identify the causes of (or contributing factors to) every accident. ${ }^{15}$ These include aspects of road condition, such as slipperiness and poor markings, which are largely within the control of the road authority. In 2015 , road factors contributed to 11 per cent of both fatal and injury crashes, ${ }^{16}$ similar to the previous ten years. ${ }^{17}$

9 Steven Penman Criminal Cars: Attributing Liability for Crashes Caused by Autonomous Vehicles (LLM Thesis, University of Auckland, 2012) at n 18.

10 Stovin v Wise [1996] AC 923 (HL) at 958; and Gorringe v Calderdale Metropolitan Borough Council [2004] UKHL 15, [2004] 1 WLR 1057 at [12], [35] and [76].

11 See Convention on Road Traffic 1042 UNTS 17 (opened for signature 8 November 1968, entered into force 21 May 1977), arts 8(5) and 13(1). New Zealand is not a signatory.

12 Brodie v Singleton Shire Council [2001] HCA 29, (2001) 206 CLR 512 at [103] and [283].

13 Lewis, above n 1, at [33].

14 At [33].

15 "Motor Vehicle Crashes in New Zealand 2015", above n 2.

16 At Figure 17.

17 See Figure 17 in the "Motor Vehicle Crashes in New Zealand" reports for the last 10 years available at "Motor Vehicle Crashes in New Zealand" (9 September 2016) Ministry of Transport <www.transport.govt.nz/>. 
But these figures are likely to under-represent the accidents where the road authority had some control over the outcome. Road authorities also control other aspects of road use which may contribute to accidents. For example, they set speed limits on road sections, design and maintain signage, and create policies as to what sorts of vehicles can use the road and under what conditions, such as heavy vehicles. In these respects, the authorities exercise a substantial degree of control over safety outcomes. And yet, just as for physical road condition, they are likely to face no sanction if they do it in a deficient way, or fail to do anything.

There is recognition of the role of roads in contributing to road safety in the current official road safety policy, Safer Journeys. This "takes a Safe System approach to road safety. This approach means working across all elements of the road system (roads, speeds, vehicles and road use)". ${ }^{18}$ "Safe roads and roadsides" impact on 9 of the 13 key areas of concern. ${ }^{19}$ This extends the scope of safer roads to taking measures to prevent some road-user behaviour with serious consequences, such as loss of control, and intersection collisions. "Loss of control" is the single biggest factor contributing to road accidents, involved in 34 per cent of fatal and 28 per cent of injury accidents. ${ }^{20}$

The strategy recognises that there are actions that road authorities could take to address these issues, such as median barriers, skid resistant surfaces and more appropriate speed limits. It notes that "New Zealand's roads are not as safe as those in other countries". ${ }^{21}$ These actions are at least partly within the control of roading authorities. The strategy also recognises that responsibility for road safety is "shared ... between road users and system designers". ${ }^{22}$ To achieve a safe system "[r]oad controlling authorities have to design, build and maintain roads and to manage speeds to protect responsible road users." ${ }^{23}$ Recognition is one step, but actual responsibility with appropriate sanctions is needed. There is no consideration given in Safer Journeys to making roading authorities legally responsible for the condition of their roads.

Roading authorities claim that they do not have enough money to cover all eventualities. ${ }^{24}$ That may be true, but their budgets are very large ( $\$ 14$ billion over the three years $2015-2018),{ }^{25}$ and

18 Ministry of Transport Safer Journeys: New Zealand's Road Safety Strategy 2010-2020 (February 2010) at 3.

19 At 12 .

20 "Motor Vehicle Crashes in New Zealand 2015", above n 2, at Figure 17.

21 Ministry of Transport, above n 18, at 14.

22 At 10 .

23 At 10 .

24 New Zealand Transport Agency "SH3 Mangaotaki South Fatal Rockfall - 28 March 2014" the report to the Coroner for Thompson, above $\mathrm{n} 1$.

25 "2015-2018 National Land Transport Programme" New Zealand Transport Agency <www.nzta.govt.nz>. 
whether they have enough money to improve safety boils down to prioritisation. Priorities are set on a "value for money" criterion. ${ }^{26}$ This is defined by the New Zealand Transport Agency in the planning and investment context as "selecting the right things to do, implementing them in the right way, at the right time and for the right price", ${ }^{27}$ which is a weaker criterion than the cost element in the HSWA. Analysis of road safety improvements goes through the same process as any other roading expenditure, based on cost-benefit analysis, discounted at six per cent. ${ }^{28}$ The same process applies to policy changes. ${ }^{29}$ There is no additional weighting for safety, so safety can be readily outweighed by cost.

The costs of poor safety do not just disappear if the highway authority does not bear them; they are reallocated, usually to individual users. As Kirby $\mathrm{J}$ put it: ${ }^{30}$

... a burden of loss distribution is imposed on the victims of the neglect of such authorities. The immunity obliges those victims to bear the economic, as well as personal, consequences, even of gross and outrageous neglect and incompetence.

The personal consequences can be severe, as a number of plaintiffs have found out when unable to claim under common law for their serious injuries. ${ }^{31}$ Even in New Zealand, where personal injury is covered by accident compensation, there can still be significant property damage involved.

There may be a duty to have safe roads in the Local Government Act $1974,{ }^{32}$ but its wording is not clear. In any case, that Act applies only to local roads, which while they account for 88 per cent of New Zealand's $94,000 \mathrm{~km}$ of public roads, ${ }^{33}$ bear only 51 per cent of the traffic. ${ }^{34}$ The more densely trafficked state highways $(11,000 \mathrm{~km})$, are administered by the New Zealand Transport Agency (NZTA) and are governed in respect of safety by the Government Roading Powers Act

26 Ministry of Transport Government Policy Statement on Land Transport 2015/16-2024/25 (December 2014) at [45] and [92].

27 "Glossary" New Zealand Transport Agency Planning \& Investment Knowledge Base <www.pikb.co.nz>.

28 New Zealand Transport Agency Economic Evaluation Manual (January 2016) at 2-4, 2-14 and 2-18.

29 Castalia Strategic Advisors Vehicle Dimensions and Mass Review: Framework for Options Assessment and Draft Rule Change Cost Benefit Analysis - Report to the Ministry of Transport (Ministry of Transport, November 2015) at 18. A slightly higher discount rate was used.

30 Brodie, above n 12, at [235]. The immunity referred to is the common law immunity of highway authorities from suit for negligent acts of omission ("non-feasance").

31 See for example Gorringe, above n 10.

32 Local Government Act 1974, s 353.

33 "State highway frequently asked questions" New Zealand Transport Agency <www.nzta.govt.nz>.

34 In terms of vehicle kilometres travelled, see "Transport volume: Vehicle travel" (27 October 2016) Ministry of Transport <www.transport.govt.nz>. 
1989 and the Land Transport Management Act 2003. In these Acts, there are only general, "target" safety duties on the road owner. ${ }^{35}$ What then is the role of the HSWA in helping make roads safer?

\section{THE HEALTH AND SAFETY AT WORK ACT 2015: COVERAGE}

Safety on road and rail might be thought to be covered by health and safety legislation, just as most other parts of the economy are. Work is required to produce both rail and road, and deficiencies in that work can cause harm. In most industries, that would create a liability under the HSWA. ${ }^{36}$ However, while it is clear that the HSWA does cover railways, ${ }^{37}$ aircraft, ${ }^{38}$ ships,${ }^{39}$ and any vehicle on a road, ${ }^{40}$ it is less clear that it covers roads in the sense of the actual roading infrastructure, even though there is no doubt that as a person conducting a business or undertaking (PCBU) ${ }^{41}$ despite its not being a profit-making body, ${ }^{42}$ a roading authority is subject to the HSWA. If it did cover roads, the safety discipline on them would become much stricter, and have a higher priority, than at present. That should lead to improved safety performance and fewer casualties.

\section{A Not Public Safety Legislation}

Coverage of roading would give the HSWA a "public safety" role, and it has been argued that on a purposive interpretation its predecessor the HSEA did not have that role. ${ }^{43}$ Its purpose was to protect workers from harm and only incidentally to protect those around the workplace, such as

35 A "target" obligation is one that can be striven for but need not be fully achieved if the policies and budgets of the authority have other priorities: see Larner v Solihull Metropolitan Borough Council [2000] EWCA Civ 359, [2001] RTR 32 at [8]; and Gorringe, above n 10, at [29] and [90].

36 While the Health and Safety in Employment Act 1992 [HSEA] has been superseded, jurisprudence on it will be considered where relevant, as it is likely to be used in Health and Safety at Work Act 2015 [HSWA] cases, especially where the wording is similar in each.

37 Railways Act 2005, s 8 [RA]. See for example WorkSafe New Zealand v KiwiRail Holdings Ltd [2015] NZDC 18904.

38 HSWA, above n 36, ss 9 and 20(2)(a).

39 Sections 10 and 20(2)(a).

40 Section 20(2)(a).

41 Definition of a person conducting a business or undertaking, s 17(1).

42 Section 17(1)(a)(ii).

43 Department of Labour v Berryman [1996] DCR 121 (DC) at 132 and 135; and Mazengarb's Employment Law (online looseleaf ed, Lexis Nexis) at [6051.9]. 
members of the public. ${ }^{44}$ Nor is occupational health and safety (OHS) legislation "directed at general product liability" once work has finished. ${ }^{45}$

The same is purported to be true of the Australian Model Bill and Act ("Model Act"), ${ }^{46}$ and so, too, the HSWA which is based on it. "[T]he [Australian Model] Bill is not intended to extend such protection in circumstances that are not related to work" ${ }^{47}$ Harm has to be work related, although those harmed need not be workers. ${ }^{48}$ The Model Act "is not intended to have operation in relation to public health and safety more broadly, without the necessary connection to work". ${ }^{49}$ A review preceding the Model Act was at pains to recommend limiting the application of OHS laws to public safety, by drafting the Act to "avoid giving it a reach that is inconsistent with" "protection of all persons from work-related harm". ${ }^{50}$ But according to Johnstone and Tooma, "[t]he drafting of the Model Act does not, however, reflect any such caution. On its language it applies to public health and safety as much as traditional workplace health and safety situations". ${ }^{51}$ They observe that "[w]here work ends and public health and safety begins is not easily ascertainable in a modern work context". 52

The Australian Review's desire to limit the scope of the Model Act has to be tempered by the need to cover third parties against work-related harm. Even in their report they include "all persons", 53 so it is inevitable that some public safety is included, as it is in ss 3(1)(a) and 36(2) of the HSWA. The "core issue" according to the review is "not whether OHS laws should protect public safety $\ldots$ but how wide the protection should be". ${ }^{4}$ The key question is how close the

44 HSEA, above n 36, s 5.

45 Inspector Campbell v Hitchcock [2004] NSWIRComm 87 at [304]; cited in Telstra Corp Ltd v Smith [2008] FCA 1859, (2008) 105 ALD 521 [Telstra FCA] at [26] per Middleton J.

46 "Model Work Health and Safety Bill" (23 June 2011) Safe Work Australia <www.safeworkaustralia.gov.au>. This is variously called a Bill and an Act. In this article, it is referred to as an Act, following the HSWA usage, except where direct quotations use "Bill".

47 Safe Work Australia "Explanatory Memorandum - Model Work Health and Safety Bill" (August 2016) at [60].

48 At [60].

49 At [61].

50 Robin Stewart-Crompton, Stephanie Mayman and Barry Sherriff National Review into Model Occupational Health and Safety Law: Second Report (Australian Government, January 2009) [Second Report] at 206, Recommendation 77 and the discussion at 18-26.

51 Richard Johnstone and Michael Tooma Work Health and Safety Regulation in Australia: The Model Act (Federation Press, Annandale (NSW), 2012) at 16.

52 At 90

53 Second Report, above n 50.

54 At 25. 
connection with work is in time and space. Hence road safety in the sense of road user behaviour would not be expected to be covered by OHS laws (leaving aside the vehicle itself as a workplace), ${ }^{55}$ but it is not so clear that work activities in building and maintaining a road are automatically excluded.

\section{KEY SECTIONS}

This part considers key sections of the HSWA, and examines them to see how far they might apply to roads, and how that differs from the application to rail.

\section{A Reasonably Practicable, s 22}

"Reasonably practicable" is a key concept in the HSWA, as it governs the scope of the principal duties in ss 36 to 43 .

Section 22 defines reasonably practicable to mean what could reasonably be done in the light of likelihood and consequence of a risk, what was or ought to have been known about it, how it might be minimised or eliminated, and cost. It is the cost element that creates a significant difference between roads and other economic activities. It requires a gross disproportion between costs and benefits before costs outweigh safety factors. ${ }^{56}$ This factor was part of the common law but is now made explicit. ${ }^{57}$ Grossly disproportionate is not defined in the Act, nor has it been judicially defined, ${ }^{58}$ but "grossly" does not admit of a small difference.

This has been applied to rail only recently, and never to road. The Land Transport Act 1993 defined a cost as reasonable if "the value of the cost to the nation [was] exceeded by the value of the resulting benefit to the nation". ${ }^{59}$ This is much the same as the current perspective on road infrastructure spending on safety. At the time, rail was also only expected to achieve safety at reasonable cost through its safety system, ${ }^{60}$ and the stricter standards of the HSEA did not apply if

55 HSWA, above n 36, s 20(2)(a).

56 HSWA, above n 36, s 22(e).

57 Edwards v National Coal Board [1949] 1 KB 704 (CA) at 712; Department of Labour v De Spa DC Christchurch CRI 30090213/93, 8 October 1993; and see Johnstone and Tooma, above n 51, at 71-73.

58 Office of the National Rail Safety Regulator Meaning of Duty to Ensure Safety So Far as is Reasonably Practicable Guideline (Adelaide, July 2016) at n 5.

59 Land Transport Act 1993, s 16(2). Re-enacted in the Land Transport Act 1998, s 189(2).

60 Transport Services Licensing Act 1989, s 6C(b) [TSLA]. There was a similar approach for aircraft and ships, now covered by HSWA, ss 9 and 10 . 
rail complied with the safety system. ${ }^{61}$ This proved contentious and was repealed after a Ministerial inquiry. ${ }^{62}$

Both the Land Transport Act provisions and the primacy of rail's safety system have been repealed. ${ }^{63}$ Rail safety became much stricter, but the safety criterion for road infrastructure has relaxed. ${ }^{64}$ In practice, as discussed above, road still takes a cost-benefit approach similar to the "reasonable cost" one, in which a project is only worthwhile if the ratio of benefits to costs exceeds one, that is, if the benefits simply outweigh the costs.

Most other industries on the other hand, including rail, are now compelled to prioritise safety by the high standard of "reasonably practicable", including the "grossly disproportionate" ratio. Economists commenting on railway safety have pointed out the distortionary impact of this rule. It effectively mandates projects with benefit: cost ratios less than one (one would be "proportionate" in their eyes) ${ }^{65}$ Thus for industries subject to the HSWA, it might be necessary to spend $\$ 3$ or even $\$ 10$ to achieve a safety benefit worth $\$ 1$, to comply with the Act. ${ }^{66}$

\section{B Workplace, s 20}

The principal case on whether a road is a place of work (now a "workplace") is Department of Labour v Berryman. ${ }^{67} \mathrm{Mr}$ Berryman was charged under the HSEA in relation to a beekeeper (not a Berryman employee) who died when his vehicle fell through a suspension bridge that Mr Berryman owned. The prosecution alleged that the bridge was a place of work, and had been allowed to decay and become unsafe. If this prosecution had been successful then it would have opened up liability for road owners generally, as it would have been difficult to distinguish a bridge from another

61 TSLA, above n 60, s $6 \mathrm{H}$.

62 WM Wilson Report of the Ministerial Inquiry into Tranz Rail Occupational Safety and Health: Report to the Ministers of Labour and Transport (Wellington, August 2000).

63 By, respectively, the Land Transport Amendment Act 2004, s 11; and RA, above n 37, sch 1.

64 The Land Transport Act provisions were replaced by even softer, more general provisions in the Land Transport Management Act 2003 [LTMA], ss 3 and 68(1), as amended by the Land Transport Management Amendment Act 2004. The equivalent provisions in the LTMA today are its purpose, s 3, and the New Zealand Transport Agency's functions, s 94.

65 Andrew W Evans "The economics of railway safety" (2013) 43 Research in Transportation Economics 137 at 141 and 142. Evans argues that when Edwards, above n 57, was decided, the measurement of safety benefits was rudimentary, and the decision was in the context of GBP 984 in damages as an analogue of the benefits to be set against the costs of prevention, whereas today the "benefits" in the calculation would be many times larger, making "grossly" an unnecessary qualification. See also M Jones-Lee and M Spackman "The development of road and rail transport safety valuation in the United Kingdom" (2013) 43 Research in Transportation Economics 23 at 34.

66 Office of the National Rail Safety Regulator, above n 58, at n 5.

67 Berryman, above n 43. 
deficient part of a road, or a private bridge from a public one. Such an outcome would in itself have corrected the uneven burden between road and rail, but the prosecution was not successful.

The definition of workplace in the HSWA is similar to that in the HSEA. For a road to be a workplace, it now needs to meet the HSWA definition: ${ }^{68}$

\section{Meaning of workplace}

(1) In this Act, unless the context otherwise requires, a workplace-

(a) means a place where work is being carried out, or is customarily carried out, for a business or undertaking; and

(b) includes any place where a worker goes, or is likely to be, while at work.

(2) In this section, place includes-

(a) a vehicle, vessel, aircraft, ship, or other mobile structure; and

(b) any waters and any installation on land, on the bed of any waters, or floating on any waters.

A place includes "any installation on land", which would include a road. A road is clearly a workplace for an employee when that person is in fact working on it, for example, repairing or maintaining it. Mr Berryman was not at the time working on the bridge. The judge thus focussed on the "customarily works" element of the HSEA definition (similar to HSWA s 20(1)(a)). In his view "customarily" denoted "some degree of frequency rather than mere intermittent activity over a number of years". ${ }^{69} \mathrm{He}$ agreed that "the carrying out of maintenance work on a structure on an intermittent basis does not mean that the structure could be a 'place of work' for all time". ${ }^{70}$ Nor did mere responsibility for maintenance mean it became a place of work. As regards Mr Berryman, then, the bridge was not a place of work. By the same reasoning, periodic maintenance on a road would not make it a workplace with respect to the road owner if work was not actually being done at the time. As well, a person customarily working involves an element of frequency - repetitive working over the course of a year, for example. Random repairs or maintenance are unlikely to be enough to bring it into the definition.

The beekeeper's crossing of the bridge was to be brief, and the judge thought that "place" connoted "a place where a person is working in more than a transitory sense". ${ }^{71}$ "[M]erely ... passing while at work" was not enough. ${ }^{72}$ The HSEA was amended to remove the transitory point,

68 HSWA, above n 36, s 20.

69 Berryman, above n 43, at 132.

70 At 132

71 At 133 .

72 At 133 
by including any place a "person moves through", ${ }^{73}$ but a transitory argument might still have appeal on the HSWA wording in s 20(1)(b). ${ }^{74}$

The way the wording of s 20(1)(a) is phrased reinforces the present nature of the work - "is being" carried out, not "has been" or "will be" nor even simply "is". This definition is slightly different from the Australian Model Act, s 8, as the HSWA definition uses the Review Committee's stronger emphasis on the present tense, adding "being" to HSWA s 20(1)(a), rather than simply "is carried out" ${ }^{75}$ The Review Committee specifically thought making a place a workplace at all times to be undesirable. ${ }^{76}$ This is however not the interpretation of the Model Act by Safe Work Australia. ${ }^{77}$ Tooma though is firm that workplace is limited to the present tense. ${ }^{78}$ The present tense of the HSWA definition makes it unlikely that it would work for the potentially many years that could elapse between the design or construction of a road and harm caused by a deficiency in that design or construction.

But on the reading in Berryman, a person only has to own or occupy (now "manages or controls") ${ }^{79}$ a workplace, which can be a workplace by virtue of another party's work there, and does not have to be the owner's own workplace. ${ }^{80}$ HSWA s $37(1)$ is still open to this reading. So the road could be made into a workplace by its user being in a work-related vehicle and the roading authority therefore made liable under s $37 .{ }^{81}$

A recent Australian case extends the "workplace" tantalisingly close to one that might include roads - but stops short. It provides some extension to the "transitory" interpretation in Berryman. In

73 HSEA, above n 36, s 2(3) substituted by the Health and Safety in Employment Amendment Act 2002, s 4(15). See also Worksafe New Zealand v Department of Corrections [2016] NZDC 18502 at [40].

74 Note the echo of Lord Denning in Burnside v Emerson [1968] 1 WLR 1490 (CA) at 1494, about transient danger like ice not being a failure to maintain a road.

75 Second Report, above n 50, at 98, Recommendation 94. Changes in the House of Representatives reinforced the HSWA section's present tense focus. In the first draft of the Bill, the clause simply read "where work is carried out", a formulation less clearly limited to the present tense: see Health and Safety Reform Bill 2014 (192-1), cl 15 .

76 Second Report, above n 50, at 97.

77 Safe Work Australia, above n 47, at [48]-[50].

78 Michael Tooma Tooma's Annotated Work Health and Safety Act 2011 (Thomson Reuters, Sydney 2012) at 25 .

79 HSWA, above n 36, s 37.

80 Berryman, above n 43, at 131.

81 The Select Committee report on the 2002 HSEA amendment recognised that a road could be a place of work for the vehicle owner: see Health and Safety in Employment Amendment Bill 2001 (163-2) (select committee report) at 4 . 
Telstra Corp Ltd v Smith, a pedestrian fell into a Telstra-owned manhole when its cover collapsed, and was injured. ${ }^{82}$ Telstra challenged a finding of liability under the Occupational Health and Safety Act 1991 (Cth), s 17, ${ }^{83}$ which was similar to HSWA s 37 .

The question was whether the manhole cover was a workplace, which was very generally defined essentially as a place where contractors or employees worked. ${ }^{84}$ Applying the logic in Berryman one might think that the interaction with the manhole cover by both Telstra and the injured party was too transitory for Telstra to be liable. Clearly the injured party would have been "at" (on) the manhole cover only very briefly, if it had not collapsed. The last time the pit was used by Telstra (by a contractor) was over two months before the accident. ${ }^{85}$

Telstra in fact contended that to be a workplace, work had to be going on at the time of the accident. ${ }^{86}$ They also referred to the objects of the Act, which included protection to third parties "arising out of the activities of such employees at work" ${ }^{87}$ They referred to a number of cases where work on infrastructure was intermittent, and because of that the relevant places were not workplaces at all times. It was argued that there was a "temporal" 88 aspect to the definition. ${ }^{89}$ In one of these cases, "[n]or could the fact that at one time, the defendant had there performed work on the pipes, thereafter make that place the defendant's place of work". ${ }^{90}$

Nevertheless, on appeal the Full Court commented that: ${ }^{91}$

There is no reason to think that an employer is not liable under s 17 if an employee creates a dangerous situation in the workplace whilst at work and the non-employee is injured after the employee has ceased work.

82 Telstra Corp Ltd v Smith [2009] FCAFC 103, (2009) 177 FCR 577 [Telstra FCAFC].

83 At [12].

84 Occupational Health and Safety Act 1991 (Cth), s 5; and Telstra FCAFC, above n 82, at [45].

85 Telstra FCAFC, above n 82, at [16].

86 Telstra FCA, above n 45, at [19].

87 At [20] (emphasis in original).

88 Telstra FCAFC, above n 82, at [47].

89 See WorkCover Authority of NSW (Inspector Paine) v Boral John Perry Industries Pty Limited New South Wales Industrial Relations Commission, 8 August 1996; and WorkCover Authority of New South Wales (Inspector Maltby) v AGL Gas Networks Limited [2003] NSWIRComm 370, both analysed in Telstra FCA, above $\mathrm{n} 45$, at [22]-[29].

90 AGL Gas Networks Limited, above n 89, at [168] as cited in Telstra FCA, above n 45, at [28].

91 Telstra FCAFC, above n 82, at [55]. 
This is on all fours with a deficiency in a road causing an injury in the absence of road authority employees, at least where the deficiency is caused by an employee's action, for example design.

"There is no need to give workplace a meaning which requires a temporal connection between the place or premises and the work to be performed."92 The manhole is designed only to enable work to be done. Moreover: ${ }^{93}$

There is no reason to limit a workplace to a place where work is being performed at any particular time.

A workplace is a place where work is performed from time to time.

Even a woolshed used only a few weeks in the year remains a workplace outside those times. ${ }^{94}$

In a recent New Zealand case, ${ }^{95}$ a place of work was interpreted clearly in the present tense, where work is being carried out. It "can only be a place where a reasonable person would appreciate that work is being undertaken", as shown by signs or "other external indications". 96 In that case, the workplace was limited to the actual site on the house where the roofing work was being done (along with relevant scaffolding). ${ }^{97}$ The adjacent driveway where the person was injured by a batten thrown off the roof was not in the place of work. This analysis applies even more strongly under the HSWA definition of "workplace", with its "being carried out" wording.

On this analysis, a road is not a workplace for the authority unless some physical work is actually going on at the time. It is a rather restrictive view.

In HSWA, s 20(1)(b), there is a potentially prospective phrase, "is likely to be". This could cover the Telstra situation, ${ }^{98}$ but not help with the roading issue, as a roading authority employee might be unlikely to visit a particular section of road very often, so is not "likely" to be there. However, a vehicle can be a workplace ${ }^{99}$ and so for work use of a vehicle, a road is also likely to be a workplace under s 20(1)(b), since that is a "place where a worker goes". The language of the HSEA s 2(3), about a place a "person moves through", has been dropped.

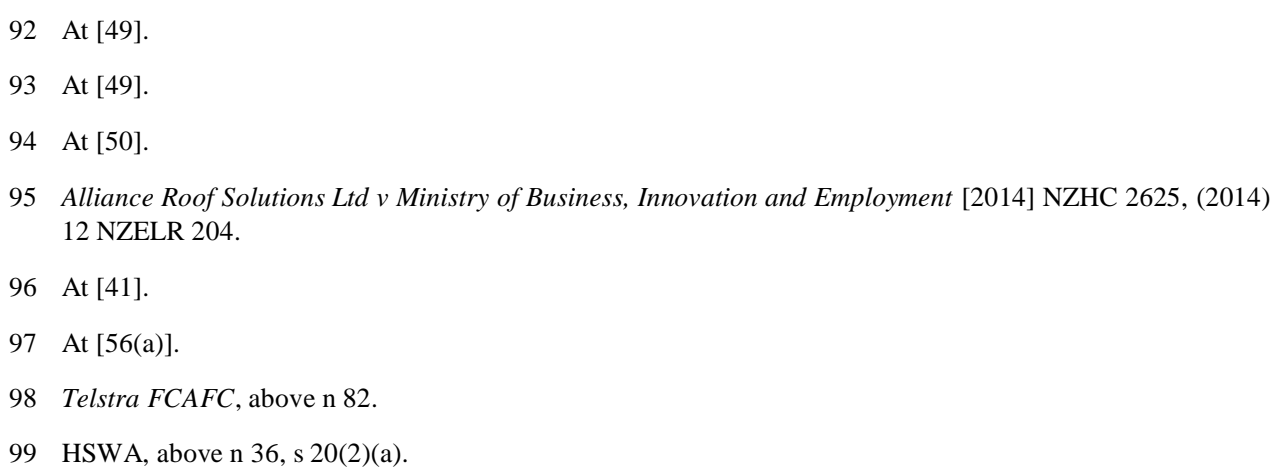




\section{PCBU duty to third parties, s 36(2)}

Section 36(2) provides that a PCBU: 100

... must ensure, so far as is reasonably practicable, that the health and safety of other persons is not put

at risk from work carried out as part of the conduct of the business or undertaking.

A road is designed, built and maintained as part of the "conduct of the business or undertaking". If any of these things are deficiently done, then prima facie that could cause harm and the roading authority may not have done all that was reasonably practicable to prevent it. Note that failure to do something is equally culpable under the section as doing something badly. Nor is there any temporal restriction in the wording of this section. As long as the risk flows from the "conduct of the business", then the duty applies. It does not have to be an immediate consequence of a particular action or inaction.

As with the similar HSEA s $15,{ }^{101}$ this has no locational constraints - harm caused anywhere by work will be caught. As long as the work is "carried out" somewhere "as part of the ... undertaking", it is caught. Section 36(2) reflects the Australian reform committee's view that some interpretations of "workplace" had limited its scope. They thought that any activity and consequence "resulting from the conduct of the business or undertaking" should be caught. ${ }^{102}$

There are subtle differences in wording between HSWA s 36(2) and HSEA s 15. The latter section focuses on the employee's action or inaction "while at work". Section 36(2) focuses on "work carried out". While the HSEA section arguably has no temporal constraint, the HSWA section appears even clearer in this regard. Work carried out at any time or in any place could put a person at risk at any other time or place. Section 36(2) may well create obligations on roading authorities.

In $R v$ Mara, ${ }^{103}$ the Court of Appeal of England and Wales considered the "third party" provision in that jurisdiction's health and safety legislation. An employee of another company used and was killed by faulty equipment owned by Mara's company for its business. Mara allowed employees of the other company to use it, without any of Mara's employees being present. The equipment was simply left for the employees of the other company to use.

The court held that Mara was rightly convicted and dismissed the appeal. The United Kingdom section imposed a duty to ensure "that persons not in his employment who may be affected thereby

100 Section 36(2).

101 Worksafe New Zealand v Department of Corrections, above n 73, at [41]-[47].

102 Robin Stewart-Crompton, Stephanie Mayman and Barry Sherriff National Review into Model Occupational Health and Safety Law: First Report (Australian Government, October 2008) at 55, Recommendation 17.

$103 R$ v Mara [1987] 1 WLR 87 (CA). 
are not thereby exposed to risks to their health or safety". ${ }^{104}$ It corresponds to HSWA s 36(2). The provision would arguably apply to those who provide roads that affect others and expose them to risk.

In an Australian case preceding the Model Bill, it was held that an undertaking was still being conducted when scaffolding blew down even though work on erecting it had finished. ${ }^{105}$ The intervening period was, however, short, and the principle may not extend to a roading situation. Foster notes a case where an authority responsible for approving the construction of a structure was held liable under health and safety laws for its collapse some years later, injuring third parties. $\mathrm{He}$ observes that today the prosecution would likely have been under the Model Law equivalent of $s$ 36(2). ${ }^{106}$ A prosecution would be possible "so long as the 'causal chain' between the business or undertaking and the harm was not too long". ${ }^{107}$ He means long in the sense of remote, many links in the chain, but the same comment probably applies to long in time. There is a clear analogy to road work - the authority does work (or should have) and sometime after an accident occurs that can be attributable to that work (or inaction).

A further avenue of escape for a roading authority might be whether its actions or inactions can be said to create risks to someone. Tooma notes that the Model Law equivalent is broad, but nevertheless there has to be "sufficient proximity to the person which makes the possibility of danger real and not too remote or fanciful". ${ }^{108}$ "Proximate" here again appears to mean close in causation terms, not necessarily in time. The concern with this article is that even obvious lapses by a roading authority attract no sanction, and borderline causality is not of critical importance.

\section{Section 37}

This section provides: ${ }^{109}$

104 Health and Safety at Work etc Act 1974 (UK), s 3(1).

105 Inspector Maltby $v$ Harris Excavations \& Demolition Pty Ltd Industrial Relations Commission of New South Wales 2 May 1997 as cited in Richard Johnstone, Elizabeth Bluff and Alan Clayton Work Health and Safety Law and Policy (3rd ed, Thomson Reuters, Sydney 2012) at 225-226.

106 Neil Foster Workplace Health and Safety Law in Australia (LexisNexis Butterworths, Sydney, 2012) at 369 citing $R$ v Mayor, Councillors, and Citizens of the City of Dandenong and Noel Bailey County Court of Victoria 8 November 1991; facts set out in Director of Public Prosecutions Ref No 1 of 1992 [1992] 2 VR 405 (SCV).

107 Foster, above n 106, at 368.

108 Tooma, above n 78, at 42 .

109 HSWA, above n 36, s 37. 


\section{Duty of PCBU who manages or controls workplace}

(1) A PCBU who manages or controls a workplace must ensure, so far as is reasonably practicable, that the workplace ... and anything arising from the workplace are without risks to the health and safety of any person.

Again, if a road is a workplace, then this would impose a duty with respect to road users. A road authority owns the road and controls it. It controls it not only in the sense of how it is made and maintained, but also in the case of New Zealand Transport Agency, controls those who use it, through licensing, and through its contract with the Police for enforcement of road rules.

But the duty need not require the road itself to be a workplace. The office where decisions are taken on design, construction and maintenance is clearly a workplace, and the decisions fall within "anything arising from the workplace". This might have been intended to be narrowly interpreted to cover only the direct risks of something physical arising, such as fumes or noise; but the section is not narrowly worded, and decisions certainly arise from a workplace. They may contain risks (albeit latent ones which might take some time to manifest themselves). ${ }^{110}$ This interpretation is reinforced by the specific coverage of design in s 39 .

Moreover, the width of s 37 would cover policies, for example those on heavy vehicle mass and dimensions, which might have safety consequences independently of the road itself. This section could be an important tool in the safety management of roads - if not curtailed by a purposive interpretation that the context of the harm has to be a direct work context. The purpose of the Bill, as noted earlier, does include coverage of people who are not workers, on equal footing, in the same subsections. ${ }^{111}$ Johnstone and Tooma note that the "Model Act is only intended to protect persons who are not workers from hazards and risks arising from work carried out as part of the business or undertaking". ${ }^{112}$ Whether the risks arising from roading are as a result of work "carried out" should not be in doubt, but the HSWA now reads "being carried out", which adds some doubt.

They go on to note that the Model Act is not built around employment or workplaces. The primary duty (in s 36 of the HSWA): 113

... is triggered by risks to all people - 'workers' and 'others' arising from work of any kind, carried out

by all kinds of workers in all kinds of work arrangements for all kinds of business organisations.

110 For example decisions on road markings: Re Angus George Johnson Donald Coroners Court Wellington CSU-2014-WGN-000262, 7 December 2015.

111 HSWA, above n 36, s 3(1)(a) and 3(2).

112 Johnstone and Tooma, above $\mathrm{n} 51$, at 62 (emphasis in original).

113 At 77 . 
In addition, "[t]he laws are not limited to workplaces and operate to capture any risk to health and safety arising from work in the conduct of any business or undertaking". ${ }^{114}$

They believe its scope to be so broad as to allow actions against tobacco companies for public health consequences. ${ }^{115}$ The harm arises from the work in making, distributing and selling cigarettes, not from any direct impact of work in the narrow sense in the factory. On this reading, it should also apply to a roading organisation. Work in making and maintaining the road, if not properly done, gives rise to risks to safety. If the cost of avoiding those risks is high, just as it would be for a tobacco company, that is not relevant unless it is "grossly disproportionate"116 to the risk.

There is a "farmers' exception" in s 37(3). ${ }^{117}$ The HSWA s 37(1) duty does not apply to a part of a farm unless work "is being carried out" there "at the time". ${ }^{118}$ The wording of s 37(3)(b)(ii) identifies the issue with respect to roads, that while they are a product of work, they may not be a workplace unless actual roading work is taking place: most of the time, work is not being carried out on a particular road. In farming terms, persons who are not working but who are injured by previous work not being adequately done (for example, on a farm bridge), or not done at all (such as no protection against falls from paths or structures), would not result in the farmer being liable. In roading terms, if such an exemption applied, persons (not working) injured by poor maintenance, construction or design equally might not have a case against roading authorities. But the absence of a similar provision for roads implies that work does not have to be actually being carried out at the time for roads to be caught.

Whether s 37 would make a road owner liable still ultimately turns on the definition of workplace, and while it is now arguable that a road is a workplace, it is likely to be looked at through the present tense and employment focused lens of somebody working there. A roading authority is unlikely to be prosecuted, let alone convicted.

\section{E Specific Duties for Particular Work, "Upstream duties", ss 38-43}

Section 38 provides that a PCBU must "so far as is reasonably practicable, ensure that ... fixtures, fittings, or plant are without risks to ... any person". ${ }^{119}$ Similar phrases are included in ss

114 At 90

115 At $88-90$.

116 HSWA, above n 36, s 22(e).

117 Section 37(3).

118 This was a change at select committee in response to farmers not wanting to be responsible for accidents to walkers using their land: see Health and Safety Reform Bill 2014 (192-2) (select committee report) at 8. The amendment made it clear that a farm (apart from the main farm buildings) was not a workplace outside those times and places where work was taking place. The exemption is only made for farmers (and only for s $37(1))$

119 HSWA, above n 36, s 38(1). 
39 (design of plant, substances or structures), ${ }^{120} 40$ (manufacture), 41 (imports), 42 (supply) and 43 (installation, construction, or commissioning). They also extend the duty to those in the vicinity of a workplace.

Sections 38-43 are inherently prospective, in that the actions of design, manufacture and so on take place over a short time and then the risks from them run. They apply to structures "to be used" as or at a workplace. ${ }^{121}$ There appears to be no time limit on their application.

Section 39 (design) in particular can only be prospective. There are no significant risks in the design process except those that result from deficiencies in the design itself, once built and used, so there is no point in having the section unless it is prospective in effect. The duty arises when the work is done, but the crystallisation of that duty may be a long way off in time. Nor is there much point if the design duty is limited to the workplace in which it was created. By definition, it will be likely to be used in another place.

This still requires that the structure is or is used at a workplace (or could reasonably be expected to be so used). ${ }^{122}$ So if the road is a workplace for the roading authority, then the duty is clear. But if it is not a workplace for the authority, it is still arguably a workplace for many users who drive vehicles in the course of their work. Sections 39-43 provide for a duty to be owed by persons in one workplace to those in another, of which a road could be an example. If the road itself is not a workplace, then for commercial vehicles, which are workplaces (including cars driven for work purposes), the designer and builder of the road could be caught by ss 39(2)(f) and 40(2)(f), which cover duties owed to those "at or in the vicinity of a workplace and who are exposed to the ... structure" at the workplace. ${ }^{123}$

Indeed, ss 39(2)(a) and 40(2)(a) could be read in the same manner: the designer or manufacturer owes duties to those: ${ }^{124}$

(a) Who, at a workplace, use the ... structure for a purpose for which it was designed or manufactured.

The vehicle is a workplace for some, and there is nothing to say that the structure referred to has to be part of the same workplace. While the drafters may have thought that the circumstances would usually involve a structure in the same workplace, they have not said so, and so have created a liability to ensure the safety of commercial users of the structure (road).

120 A "structure" includes "anything that is constructed", which would include a road: see HSWA, above n 36, s 16. See also Black v Shaw and Official Assignee (1913) 33 NZLR 194 (SC) at 196.

121 HSWA, above n 36, ss 39(1)(c), 40(1)(c), 41(1)(c), 42(1)(c) and 43(1).

122 Section 39(1)(c).

123 Sections 39(2)(f) and 40(2)(f).

124 Section 40(2)(a). Section 39(2)(a) is in similar terms. 
This does however suffer from the disadvantage of only impacting on a subset of vehicle users, and so is not of general application. Those using the road for non-commercial purposes would not be covered, although the specific exemption for those using a facility for leisure is not carried over from HSEA s 16. It would be an unsatisfactory position to have the law only protect a subset of those who use the road, and this may in itself indicate a forced reading of it. It would be much more satisfactory to make it clear that the duties are held in respect of all users, by clarifying that the HSWA does apply to roads.

\section{F Personal Duty of Workers and All Persons to Others, ss 45, 46}

As well as the PCBU, any worker must take reasonable care to avoid adversely affecting their own and others' safety. ${ }^{125}$

The phrase "reasonable care" is not defined. It is arguably a lesser obligation than s 36's duty to ensure safety "so far as is reasonably practicable". ${ }^{126}$ It nevertheless is not limited by time, and a worker (widely defined) ${ }^{127}$ for a roading authority could be liable for careless acts or omissions.

Under s 46, any person (including a PCBU or a worker) at a workplace has to take reasonable care to avoid harm to anyone else, inside or outside the workplace, and at any time. ${ }^{128}$ According to Foster, the Australian equivalent, s 29, is a new and untested provision, going beyond workplace safety into the area of public safety, although his examples are of members of the public who are in places readily identifiable as workplaces such as shopping centres or public libraries. ${ }^{129}$

\section{POSSIBLE REFORMS}

The lack of HSWA safety liability for roads is anomalous relative to most other activities, and could contribute to the number of road casualties. It distorts competition with rail, which is clearly subject to the HSWA, as well as having the HSWA duties mirrored and extended in a specific Act. ${ }^{130}$ Could then the HSWA be easily changed to cover roads?

125 Section 45 .

126 Foster, above n 106, at 410.

127 HSWA, above n 36, s 19.

128 Section 46.

129 Foster, above n 106, at 411.

130 RA, above n 37, s 5. The duties are extended beyond those applying to people at work by s 7, which covers harm by rail activities to "individuals", without restricting the context to work. Section 8 provides that the HSWA is not limited by the RA. The railway has been prosecuted under the former HSEA several times; see for example KiwiRail Holdings, above n 37. 


\section{A Reducing the "Grossly Disproportionate" Ratio of Costs to Benefits}

The grossly disproportionate cost standard in HSWA, s 22(e) applies to rail, both through the HSWA and the RA. ${ }^{131}$ On the other hand, the standard adopted for roading works and maintenance is a reasonable cost one, where benefits are expected to exceed costs, or in the terms used in the HSWA, benefits are at least proportionate with the costs.

One potential option to bring rail on to the same footing as road is to delete "grossly" from para (e) - so it simply reads "disproportionate", or even "whether the cost is proportionate to the risks". Going further, the section would still work if it stopped at "minimising the risk", leaving the ratio of costs and risks unstated, but implicitly in balance. Another option would be to revise para (e) so it simply referred to "whether the costs of eliminating or avoiding the risks are reasonable". What is reasonable in terms of costs could be defined as it once was in the Land Transport Act 1998. ${ }^{132}$ In these ways, road and rail would be placed on an even footing.

To be consistent, a change would need to be limited to rail infrastructure, so that operations continued to be treated like any other industry (including operation of road vehicles in a work situation), which would not be simple to do.

Using grossly disproportionate is a distortion that affects the whole of workplace safety, biasing expenditure towards safety compared with other applications for the expenditure. It would be logical to address this, and doing so would help balance the obligations of road and rail without the difficulties identified above. But changing the health and safety legislation for all industries is not the point of this article.

Changing the law to reduce rail's obligations could be difficult. And, apart from amending grossly disproportionate in general, a lessening of rail's safety oversight is not an easy position to advocate, nor one that on balance would be in society's interests. These changes may not be possible to achieve.

\section{B Make Health and Safety Legislation Apply to Roads}

The health and safety legislation is where safety rules have the most impact in New Zealand, rather than in general tortious duties, given the accident compensation regime and inability to sue for personal injury. If it is good enough for rail and most other undertakings to meet the "reasonably practicable" test, then it should be good enough for road. Then we would have a common standard for safety legislation.

One way of addressing the problem of the uncertainty of the HSWA's coverage of roads is to include a section directly declaring them to be covered by the HSWA. There are precedents for such

131 RA, above n 37, s 5, as amended by HSWA, above n 36, sch 5 .

132 Section 189(2), as originally enacted. 
a provision, in HSWA ss 9 (aircraft) and 10 (ships). A similar approach to s 10 could be taken for roads, simply declaring that the Act applies to roads, whether or not the work is actually taking place at the time. Such a section could read:

\section{A Application of Act to roads and other infrastructure}

(1) This Act applies to roads, whether or not work is currently taking place on the road.

(2) Roads includes bridges and tunnels the road crosses or goes through; and all ancillary works and equipment such as signs and signals.

(3) This Act does not apply to drivers and owners of vehicles on a road when the vehicle is not being used for work.

The section could cover wider infrastructure than roads, along the lines of the amendments proposed below to $\mathrm{s} 20(1)(\mathrm{c})$ of the HSWA. It may be that that paragraph would not then be necessary, but leaving the present tense wording of s 20 untrammeled would invite later argument about the contradiction between the two. For the avoidance of doubt, both should be included, or at least s 20(1)(c) made subject to $\mathrm{s} 9 \mathrm{~A}$.

A further issue is the definition of workplace, with its present tense emphasis, through the use of "is being carried out". A road will be a workplace for someone working on it, including a driver or occupant of a vehicle engaged in work activities. This may well make it a workplace in itself, but it would be better to make it clear (and as well protect the non-work users). The simplest way to address these issues would be to define a road as a workplace with respect to the road controlling authority. Adding a para (c) to s 20(2), which already lists places that are included as workplaces, would be deceptively simple. But in doing that the road would still be subject to the language in subs (1), which defines workplace in the present, where work is actually taking place.

Changing the definition for all parties is unlikely to be acceptable. But there is a class of place where work can create hazards some time after the work has taken place, and their users and neighbours deserve the HSWA's protection. In these cases, the interval between the work creating the danger and its crystallisation into an accident may be too long to be characterised in the present tense terms used in s 20. It could be months or even years. Thus, a new para (c) to s 20(1) should be included to apply to roads:

... a workplace-

(c) includes a road, road bridge or road tunnel, even if work is not currently taking place there.

Potentially it could apply to all such places:

(c) includes a road, bridge, wharf, tunnel, railway, runway, taxiway, electricity transmission line, pipeline or similar infrastructure, even if work is not currently taking place there. 
The concept of such a place (and the doubt over its status) has been recognised in the farmers' exemption in s 37, discussed above. A farm was potentially a workplace at times outside those where work was taking place. The amendment made it clear it was not a workplace in those circumstances. Equally the position with infrastructure can be clarified, in the opposite way. The motivations for the farming change are unlikely to apply to transport infrastructure. ${ }^{133}$

If this is done, then specific legislation applying the HSWA standard for rail and other transport infrastructure would not be necessary.

\section{Dealing with the "Public Safety" Obligation}

One of the aspects that sets rail and road apart from the bulk of workplaces is the presence of a public safety obligation, that is an obligation to people who use their infrastructure or are in the vicinity of it, but are not workers there, and who may be exposed to risk from the activities. Since the HSWA is arguably not intended to be a public safety statute, these activities may be outside its scope. The distinction is doubtful in the case of rail, since the obligations to protect others at or near a workplace will only crystallise when work (such as driving a train) is actually going on (and so public safety is covered by the presence of work), but it is clearer in the case of road, in the absence of the amendment suggested in the previous section. Rail accidents will always involve an employee or contractor, but roads are designed for use by third parties without the presence of a roading authority employee, making road accidents only covered by HSWA in a public safety sense. ${ }^{134}$

In Britain, this has been recognised with respect to rail, and the Railways Act 1993 (UK), s 117, provides for all safety oversight to be done through their Health and Safety at Work etc Act 1974 (UK). It is a brief provision and the process of including public safety coverage is simple. Certain statutory provisions about rail safety are deemed to be within the coverage of and enforced through the Health and Safety at Work etc Act, including provisions about construction of railways and rail vehicles and the protection of the general public. The purposes of that Act are expanded to include: ${ }^{135}$

... protecting the public (whether passengers or not) from personal injury and other risks arising from

the construction and operation of transport systems to which this section applies.

133 Health and Safety Reform Bill 2014 (192-2), above n 118.

134 A gap in HSWA coverage analogous to road could arise on rail where passengers of a third party operator (suburban or enthusiast trains) were harmed by a latent deficiency of the track caused by its owner's staff, long after the deficiency was caused. Such a case would be covered by the RA, above n 37, which does not relate just to workers or incidental work activities, but to the functions of operating a railway and the safety of all individuals: see ss 3(a)(i), 7 and 9(1). The same gap exists with respect to roading but there is no Roads Act to fill it.

135 Railways Act 1993 (UK), s 117(2)(b). Railtrack plc v Smallwood [2001] EWHC 78 (Admin), [2001] ICR 714 discusses the public safety aspects of a prohibition order. 
Such an approach could be taken for road here, to simply say that the public safety aspects of road operation are covered by the HSWA. The amendment already suggested to s 20 may suffice, along with simply including within the HSWA's purpose statement a paragraph that covers construction of infrastructure assets, and protecting the public. Section 3(1) of the HSWA could be amended by adding after para (a):

(aa) protecting the public from personal injury and other risks arising from the construction,

maintenance and operation of transport and other infrastructure activities.

This would need a definition of "infrastructure", along the same lines as the s 20(1)(c) amendment. It would also cover rail, but not vehicles, which in both road and rail are operational assets and reasonably equally covered now.

\section{CONCLUSION}

The HSWA applies to rail, but is not so clear that it applies to roads. While a purposive argument could be made about restricting its application to situations closely linked to employment, it also includes a purpose to protect others (other than employees) within the first objective (which has been referred to as the "primary duty"). ${ }^{136}$ Its provisions are not all restricted to a workplace, and indeed the protection for "others" is expressed in wide terms. It is capable of supporting a prosecution of a roading authority, especially in relation to a work-use vehicle, though the issue will be whether the workplace safety authority will want to take that action. The authorities administering the HSEA have not taken action to prosecute roading authorities for road deficiencies under that Act, ${ }^{137}$ and it has been over 10 years since the HSEA was amended to counter the implications of Berryman. ${ }^{138}$

The HSWA could be relatively simply amended to clarify and improve its coverage of roads. It could also be amended to cover public safety aspects of other infrastructure, avoiding the need for separate specific legislation.

136 HSWA, above n 36, s 3(1)(a); and Johnstone and Tooma, above n 51, at 62.

137 Other than in the immediate context of roadworks: see Department of Labour v Works Infrastructure Ltd DC Tauranga CRN 35100091323/33, 11 November 2004.

138 Berryman, above n 43. 
